\title{
Immunotoxic Effect of Selenium Following Subacute Exposure in Broilers
}

\author{
Shonam Tamrakar ${ }^{1}$, M. Mondal ${ }^{2 *}$, R.C. Ghosh ${ }^{1}$ and N. Sahu ${ }^{1}$ \\ ${ }^{1}$ Department of Veterinary Pathology, College of Veterinary Science and Animal Husbandry, \\ Chhattisgarh Kamdhenu Vishwavidyalaya, Durg, Chhattisgarh, India \\ ${ }^{2}$ Department of Veterinary Clinical Complex, F/O-Veterinary and Animal Sciences, West \\ Bengal University of Animal and Fishery Sciences, Kolkata, India \\ *Corresponding author
}

\section{A B S T R A C T}

\begin{tabular}{|l|}
\hline Ke y w o r d s \\
Broiler, \\
$\begin{array}{l}\text { Immunotoxicity, } \\
\text { Selenium }\end{array}$ \\
\hline Article Info \\
\hline $\begin{array}{l}\text { Accepted: } \\
\text { 10 August } 2018 \\
\text { Available Online: } \\
\text { 10 September } 2018\end{array}$ \\
\hline
\end{tabular}

\section{Introduction}

Poultry industry is designated as major dynamic and rapid growing segment amongst agricultural and livestock sectors in India. Selenium (Se) is required in the diets of mammals and poultry, but can easily be over supplemented due to a narrow range of safety between ideal and toxic concentrations.

Sodium selenate and sodium selenite are used as supplements to poultry and livestock feed to promote growth and prevent selenium deficiency diseases. Selenium can be toxic for all animals, such as invertebrates, fishes, amphibians and reptiles, birds, mammals and humans depending on the dose and duration of intake and also on its chemical form. Traditionally, Se has been added to poultry diets via inorganic sources, such as sodium selenite $\left(\mathrm{Na}_{2} \mathrm{SeO}_{3}\right)$. Selenium in combination with vitamin $\mathrm{E}$ is used frequently in poultry for immunomodulation.

The immunomodulatory effect and toxicity of inorganic selenium, such as selenite and selenate, has been heavily studied in animals, aquatic birds and fishes. But till date work on immunotoxicity of Se is scanty. So, present study has designed to demonstrate the immunotoxic effect of selenium following subacute exposure in broilers. 


\section{Materials and Methods}

\section{Chicken and diet}

The experimental investigation was planned to adjudge the toxicopathological effects of sodium selenite on cell mediated immune response in broilers after obtaining approval from Institutional Animal Ethics Committee. Clinically healthy one hundred and twenty, day old, Cobb- 400 broiler chicks of both sexes, weighing 45- $49 \mathrm{~g}$ were obtained from a commercial hatchery and were reared on deep litter system of housing using rice husk with provision of artificial light at night. The chicks were fed a standard commercial feed starter upto14 days, thereafter a grower diet upto 28 days and finisher upto 35 days. Chickens were allowed access to the diets and fresh and clean drinking water ad libitum. All the experimental chicks were kept under close observation during entire period of study.

\section{Experimental design}

Individually weighed chicks were randomly divided into 4 groups of 30 chicks; each group consisting of 3 replicates of 10 chicks. Chicks of group-I was kept as untreated control and was given only basal diet. Chicks of groupsII, III and IV were given diet with selenium @ 2, 6 and $10 \mathrm{ppm}$ respectively from day first of experiment for 35 days. Six broilers from each group were used for assessing the cell mediated immunity. The remaining broilers from each group were kept for haematological, biochemical and pathological study. When the chicks reached 35 days of age, the feeding trial was terminated.

\section{Cell mediated immunity (CMI)}

Cell mediated immune response was measured by Di Nitro Fluro Benzene (DNFB) test as described by Phanuphak et al., (1974) and later slightly modified by Tamang et al.,
(1988). Featherless area was marked on both sides of abdomen and cleaned thoroughly with acetone and air dried. Right lateral side of abdomen was used for DNFB application whereas left side served as control. 2000 $\mu \mathrm{g}$ of DNFB in $0.1 \mathrm{ml}$ of acetone and olive oil (4:1) was applied on the right marked area on the abdomen using a plastic ring to avoid spillage. The sensitized birds were challenged with $50 \mu \mathrm{g}$ of DNFB in $0.1 \mathrm{ml}$ of acetone and olive oil $(4: 1)$ on the same area on $14^{\text {th }}$ day after initial sensitization. The response to DNFB was assessed by measuring the skin thickness using engineer's micrometer on 0,24 and 48 hours of post challenge with three readings each and the overall mean skin thickness was calculated.

\section{Haematology}

At the end of the experiment on day 35 blood samples were collected in heparinised vials from jugular veins. Thin blood smears were prepared for differential leukocyte count during blood collection. The total leucocytic count (TLC) was done as per Jain (1986), by using W.B.C. diluting fluid (Merck Limited, Mumbai - 400018) and Haemocytometer (Neubauer's chamber and WBC diluting pipette).

The differential leucocytic count (DLC) was done as per Coles (1986), using Leishman's stain (Merck Limited, Mumbai- 400018). The percentages of different leucocytes were determined by examining the stained blood smear under oil immersion objective lens of light microscope.

\section{Histopathology}

The tissue samples of spleen were collected in $10 \%$ neutral buffered formalin for histopathological studies. The tissues were thoroughly washed in running water; dehydrated in ascending grades of alcohol; 
cleared in benzene and embedded in paraffin at $58^{\circ} \mathrm{C}$. The paraffin embedded tissue sections of 4 to $5 \mu \mathrm{m}$ were obtained and stained with haematoxylin and eosin $(\mathrm{H}$ and E) as per the method described by Bancroft and Stevens (1990) with slight modifications. The stained sections were examined under light microscope and the lesions were recorded.

\section{Statistical analysis}

Data obtained in different parameters were statistically analyzed by using complete randomized design (CRD)-single factor analysis of variance by Snedecor and Cochran (1968).

\section{Results and Discussion}

\section{Cell mediated immune response (CMI)}

In the present study the mean increment in abdominal skin thickness of treated broilers at different hours post challenge were depicted in Table 1. Broilers exposed to the challenge dose of DNFB exhibited erythema, oedematous changes and vesicle and scab formation.

Broilers of all Se treated groups had pronounced changes than that of control. Present study indicated that the contact sensitivity to DNFB could be conveniently applied in broilers for studying CMI response using abdominal skin in place of comb as test site unlike the previous method (Tiwari and Goel, 1984).

Control broilers had significant decrease in abdominal skin thickness as compared to selenium treated broilers at 24 and 48 hours post challenge which clearly indicated the immunosuppression due to selenium toxicity. Present findings of significant decrease CMI response on DNFB test was in agreement with the findings of earlier workers in alphamethrin intoxicated broilers (Singh et al., 1999).

Contact hypersensitivity is a T- cell mediated cutaneous immune response to reactive haptens (Elmets and Bowen, 1986). After exposure of the skin to contact allergens, haptens covalently bind to discrete amino acid residues on carrier proteins.

The epidermal Langerhans cell, a member of the dendritic-cell family, takes up haptenated proteins and processes them into antigenic peptides which are transported to the cell surface in association with major histocompatibility complex molecules (Wang et al., 2001).

Matos et al., (2005) reported that DNFB induces the activation of the extra cellular signal-regulated kinases ERK1/2 and p38, and also up regulates CD40 expression.

\section{Haematology}

Results on the haematological alteration due to subacute selenium toxicity in broilers were given in Table 2. A significant $(p \leq 0.05,0.01)$ decrease in leucocyte count was observed in broilers of all intoxicated groups. The present study also showed that selenium caused a significant eosinopaenia and leukopaenia due to lymphopaenia in all the intoxicated broilers. This finding was in agreement with the changes induced by Se in broiler chickens earlier (Kumar et al., 2011). Marked leucopaenia in subacute selenium toxicity in the present study was probably due to their cumulative effect following daily administration. Continuous exposure to $\mathrm{Se}$ may then lead to lymphopaenia, which may have an immunosuppressive effect in broilers. The marked lymphopaenia in the present study might have occurred due to the toxic effect of sodium selenite on bone marrow and stress (Goyal et al., 1986). 
Table.1 DNFB response (mean increase in skin thickness in $\mathrm{mm}$ ) of broilers exposed to subacute selenium toxicity (Left side served as vehicle control and right side treated with DNFB)

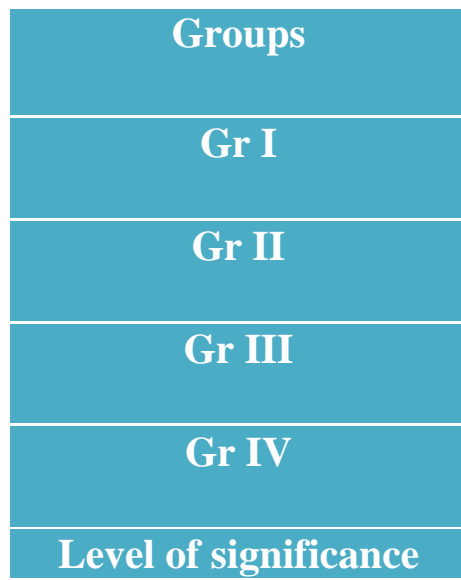

\begin{tabular}{|c|c|c|c|}
\hline $\begin{array}{c}\text { Abdominal } \\
\text { side }\end{array}$ & $\begin{array}{c}\text { Before } \\
\text { sensitization }\end{array}$ & \multicolumn{2}{|c|}{ After sensitivation } \\
\hline Left & $0.55 \pm 0.04$ & $0.63 \pm 0.08$ & $\mathbf{2 4} \mathbf{~ h r}$ \\
\hline Right & $0.58 \pm 0.04^{\mathrm{a}}$ & $3.22 \pm 0.10^{\mathrm{b}}$ & $3.47 \pm 0.16^{\mathrm{b}}$ \\
\hline Left & $0.57 \pm 0.05$ & $1.81 \pm 0.17$ & $1.77 \pm 0.22$ \\
\hline Right & $0.61 \pm 0.05^{\mathrm{a}}$ & $3.37 \pm 0.09^{\mathrm{b}}$ & $3.64 \pm 0.09^{\mathrm{b}}$ \\
\hline Left & $1.25 \pm 0.07$ & $1.68 \pm 0.09$ & $1.65 \pm 0.09$ \\
\hline Right & $1.33 \pm 0.08^{\mathrm{b}}$ & $1.90 \pm 0.14^{\mathrm{a}}$ & $2.71 \pm 0.18^{\mathrm{a}}$ \\
\hline Left & $1.15 \pm 0.05$ & $1.47 \pm 0.16$ & $1.47 \pm 0.17$ \\
\hline Right & $1.21 \pm 0.06^{\mathrm{b}}$ & $1.65 \pm 0.13^{\mathrm{a}}$ & $2.86 \pm 0.13^{\mathrm{a}}$ \\
\hline & $* *$ & $* *$ & $* *$ \\
\hline
\end{tabular}

Table.2 Effect of induced subacute toxicity of Selenium on haematological changes in broilers

\begin{tabular}{|c|c|c|c|c|c|}
\hline \multirow[t]{2}{*}{ PARAMETERS } & \multicolumn{4}{|l|}{ GROUPS } & \multirow{2}{*}{$\begin{array}{l}\text { Level of } \\
\text { significance }\end{array}$} \\
\hline & Group I & Group II & Group III & Group IV & \\
\hline TLC ( $\left.10^{3} / \mathrm{cu} . \mathrm{mm}\right)$ & $31.18 \pm 0.36^{\mathrm{d}}$ & $29.19 \pm 0.21^{\mathrm{c}}$ & $27.21 \pm 0.15^{b}$ & $26.08 \pm 0.27^{\mathrm{a}}$ & $* *$ \\
\hline Lymphocyte (\%) & $74.5 \pm 1.12^{b}$ & $64.5 \pm 2.19^{\mathrm{a}}$ & $61.83 \pm 1.42^{\mathrm{a}}$ & $60.83 \pm 0.60^{a}$ & $* *$ \\
\hline Heterophil (\%) & $16 \pm 0.93^{\mathrm{a}}$ & $19.5 \pm 1.45^{b}$ & $20.16 \pm 1.11^{b}$ & $21.83 \pm 0.48^{b}$ & $* *$ \\
\hline Monocyte (\%) & $5.33 \pm 0.80^{\mathrm{a}}$ & $13.33 \pm 0.67^{b}$ & $14.5 \pm 0.62^{b}$ & $14.66 \pm 0.49^{b}$ & $* *$ \\
\hline Eosinophil (\%) & $2.83 \pm 0.31^{b}$ & $0.83 \pm 0.31^{\mathrm{a}}$ & $1.33 \pm 0.21^{\mathrm{a}}$ & $0.83 \pm 0.31^{\mathrm{a}}$ & $* *$ \\
\hline Basophil (\%) & $1.33 \pm 0.21^{\mathrm{a}}$ & $1.83 \pm 0.17^{\mathrm{a}}$ & $2 \pm 0.16^{\mathrm{a}}$ & $1.83 \pm 0.17^{\mathrm{a}}$ & NS \\
\hline
\end{tabular}

Values indicate Mean \pm S.E. Superscripts may read row wise for comparison of means. NS - No significance difference. $\left({ }^{*} \mathrm{P} \leq 0.05\right)$ and $(* * \mathrm{P} \leq 0.01)$

Fig.1 Section of spleen (group III) showing oedematous changes. H \& E × 400

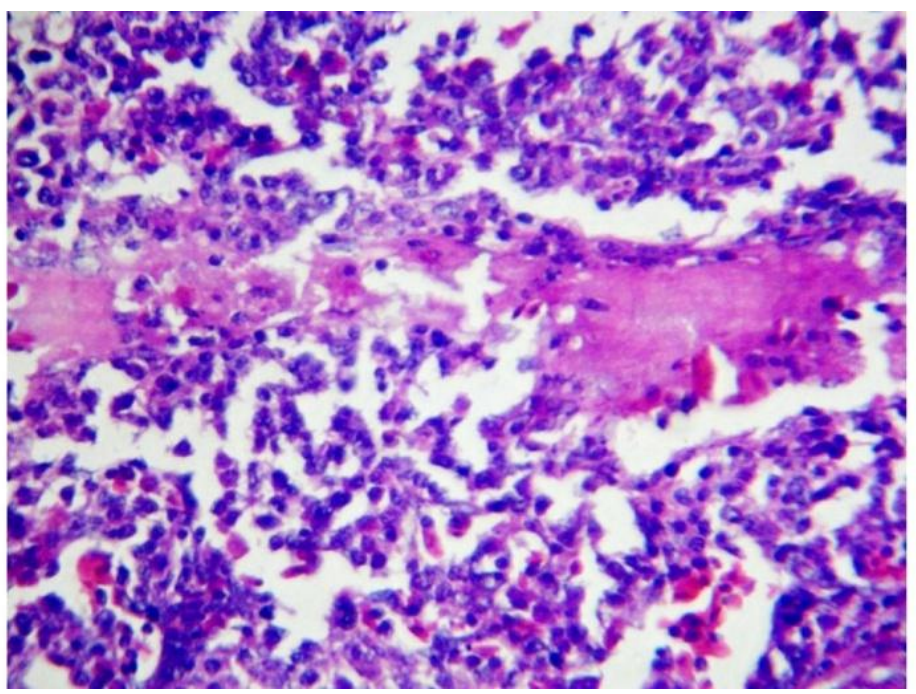


Fig.2 Section of spleen (group IV) showing severe depletion of lymphocytes and vacuolation. $\mathrm{H} \& \mathrm{E} \times 400$

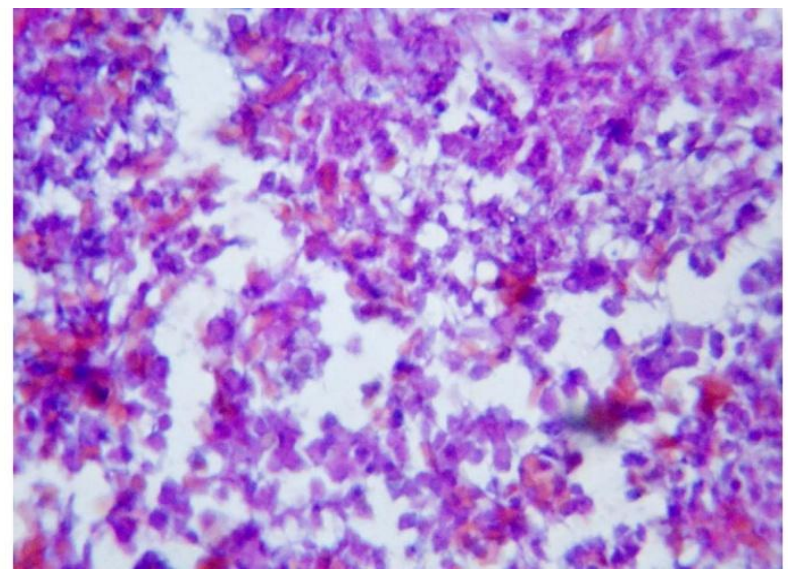

Fig.3 Section of bursa of Fabricius (group IV) showing vacuolation and severe depletion of lymphocytes. H \& E × 400

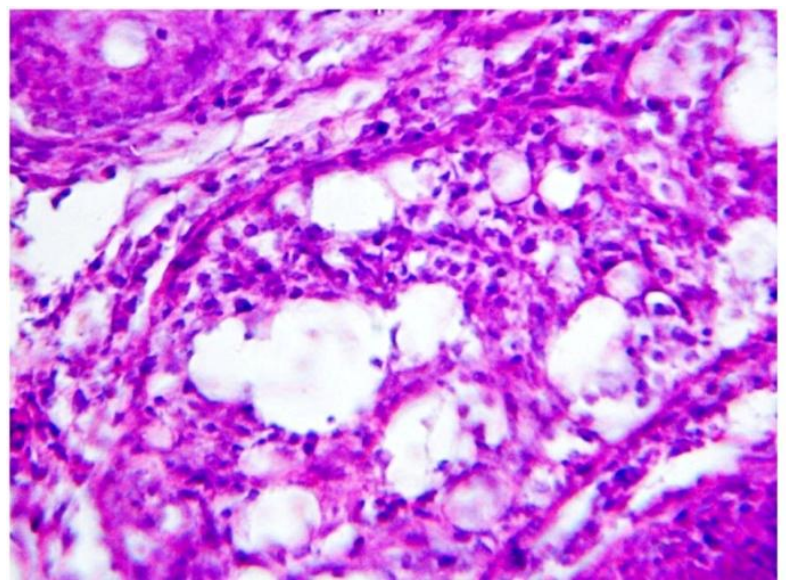

Fig.4 Section of thymus (group IV) showing severe medullary lymphocytic depletion. $\mathrm{H} \& \mathrm{E} \times 100$

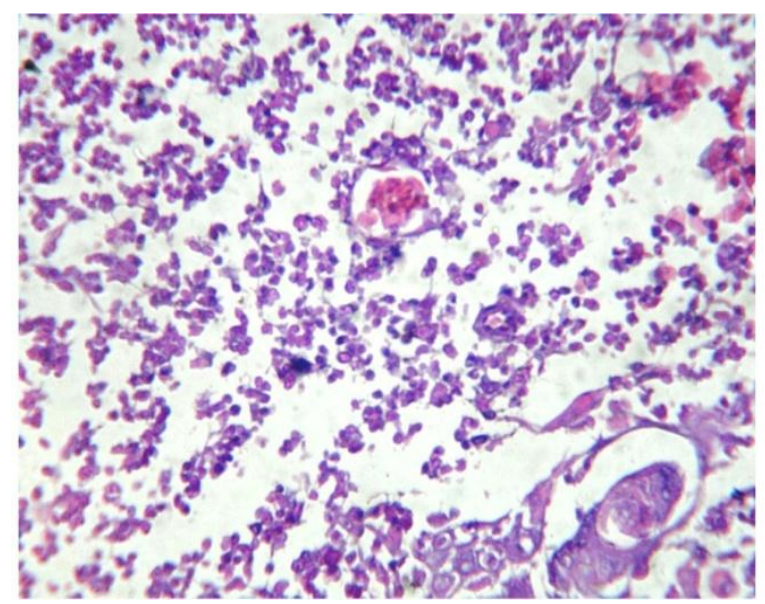




\section{Histopathology}

Histologically the spleen of intoxicated broilers had congestion, oedematous changes (Fig. 1), severe depletion of the lymphocytes and vaccuolation (Fig. 2). The histopathological changes of spleen were closely corroborated with the findings of Jacevic et al., (2011). In the present study the marked lymphocytolysis of the germinal center of the splenic follicles correlates with the findings related to suppression of the CMI and indicated that selenium causes immunosuppression. Microscopically induced broilers revealed serous exudation, vaccuolation and depletion of lymphocytes in the follicles of bursa of Fabricius (Fig. 3). Thymus of $\mathrm{Se}$ intoxicated broilers had congestion, haemorrhages, oedematous changes and severe medullary lymphocytic depletion (Fig. 4). Histological changes of lymphoid organs in selenium induced broilers were in close conformity with the findings of Narayani (2010) who reported severe lymphocytosis in the germinal center of the spleen, bursa of Fabricius and thymus in alphamethrin treated broilers. So, the present study suggested that the selenium toxicity causes immunosuppression in the broilers.

\section{References}

Brancroft, J.D. and Stevens, A. (1990). Theory and practice of histological techniques. Churchill Livingstone, Edinburgh, pp. 113-305.

Coles, E.M. (1986). Veterinary Clinical Pathology. $4^{\text {th }}$ Edn., W.B. Saunders company, West Washington square, Philadalphia.

Elmets, C.A. and Bowen, K.D. (1986).Immunopathological suppression in mice treated with hematoporphyrin derivative photoradiation. Cancer Res.46: 1608-1611.
Goyal, B.S., Garg, S.K. and Garg, B.D. (1986). Malathion induced hyperadrenal activity in WLH chicks. Current Sci., 55: 526-528.

Jacevic, V., Jokic, G., Simic, V.D., Bokonjic, D., Vucinic, S. and Vuksa, M. (2011). Acute toxicity of sodium selenite in rodents: Pathomorphological study. Military Med. Sci. Lett. (Voj.Zdrav.Listy) 80: 90-96.

Jain, N.C. (1986). Haematological techniques-In Sclams Veterinary Haematology. $4^{\text {th }}$ Edn., Lea and Febingerr. Philadelphia. pp. 20-86.

Kumar, D., Niyogi, D., Ali, I. and Mukhopadhayay, S.K. (2011). Clinicopathological study of induced selenium toxicity in broiler chickens.Indian J. Anim. Hlth., 50 (2): 15-20.

Matos, T.J., Duarte, C.B., Goncalo, M. and Loes, M.C. (2005). DNFB activates MAPKs and upregulates CD40 in skinderived dendritic cells. J. Dermato. Sci.39:113-123.

Narayani. (2010). Toxicopathological studies on alphamethrin in broiler chicks. M.V.Sc. Thesis submitted to Indira Gandhi Krishi Vishwvidyalaya, Raipur, Chhattisgarh.

Phanuphak, P., Moorhead, J.W. and Claman, H.N. (1974). Tolerance and contact sensitivity to DNFB in mice. In vivo detection by ear swelling and correlation with in vitro cell stimulation. J. Immunol., 112: 115-123.

Singh, S.P., Sharma, L.D. and Chauhan, R.S. (1999). Effect of single oral dose of alphamethrin on immune response of chicks. J. Immunol. Immunopathol., 1(1): 63-66.

Snedecor, G.W. and Cochran, W.G. (1968). Statistical Methods. $8^{\text {th }}$ Edn. Iowa State University Press, Ames, Iowa. 
Tamang, R.K. (1987). Comparative pathology of pyrethroid and organophosphate pesticides intoxication in mice and goats. M.V.Sc. Thesis submitted to Birsa Agricultural University, Ranchi, Bihar.

Tiwari, B.K. and Goel, M.C. (1984). Contact sensitivity to DNCB in normal and cell mediated immunity deficient chickens: In vivo detection and correlation with lymphocyte transformation and Graft versus Host reaction. Vet. Immunol.Immunopathol.8: 329-339.

Wang, B., Feliciani, C., Freed, I., Cai, Q. and Saunder, D.N. (2001). Insights into molecular mechanisms of contact hypersensitivity gained from gene knockout studies. J. Leukoc. Biol.70:185-191.

\section{How to cite this article:}

Shonam Tamrakar, M. Mondal, R.C. Ghosh and Sahu, N. 2018. Immunotoxic Effect of Selenium Following Subacute Exposure in Broilers. Int.J.Curr.Microbiol.App.Sci. 7(09): 16301636. doi: https://doi.org/10.20546/ijcmas.2018.709.196 